noblot patterns obtained by using four strains of Borrelia burgdorferi and sera from naturally exposed dogs. J Clin Microbiol 26:2287-2291

22. Wilske B, Preac-Mursic V, Schierz G, Gueye W, Herzer P, Weber K 1988 Immunochemische Analyse der Immunantwort bei Spätmanifestationen der Lyme Borreliose. Zbl Bakt Hyg A 267:549-558

23. Barbour AG, Heiland RA, Howe TR 1985 Heterogeneity of major proteins in Lyme disease Borreliae: a molecular analysis of North American and European isolates. J Infect Dis 152:478-484

24. Wilske B, Preac-Mursic V, Schierz G, Busch KV 1986 Immunochemical and immunological analysis of European Borrelia burgdorferi strains. Zbl Bakt Hyg A 263:92-102

25. Kristoferitsch W, Mayr WR, Partsch H, Neumann R, Stanek G 1986 HLA-Dr in Lyme borreliosis. Lancet 2:278

26. Steere AC, Duray PH, Butcher EC 1988 Spirochetal antigens and lymphoid cell surface markers in Lyme synovitis. Arthritis Rheum 31:487-495

27. Satz N, Ackermann R, Gern L, Aeschlimann A, Ott A, Knoblauch M 1988 Zur Epidemiologie der Infektion mit Borrelia burgdorferi. Schweiz Med Wochenschr 118:422-426

\title{
Announcements
}

\section{Abstract Deadline}

The American Pediatric Society and The Society for Pediatric Research announce the abstract deadline for the 1990 Annual Meeting (May 7-11, 1990, Anaheim Hilton \& Convention Center, Anaheim, CA) has been set as January 4, 1990.

For further information contact: 2650 Yale Blvd., S.E., Suite 104, Albuquerque, NM 87106 (505)764-9099.

Society for Behavioral Pediatrics 7th Annual Meeting

The Society for Behavioral Pediatrics will conduct its 7th Annual Meeting on November 9-10, 1989 at the Royal Sonesta Hotel in Cambridge, Massachusetts. A special session honoring Dr. T. Berry Brazelton will be held November 11. For further information and registration forms, contact Ms. Noreen Spota at (215) 248-9168. 